\title{
Greek Sovereign Debt: Addressing Economic Distress and Growth in the Euro Area
}

\author{
Panayotis Alexakis \\ National and Kapodistrian University of Athens, Greece \\ Gikas Hardouvelis \\ University of Piraeus \& Ex Minister of Finance of Greece, Greece \\ Dean Paxson \\ University of Manchester, UK \\ Gordon Sick \\ University of Calgary, Canada \\ Lenos Trigeorgis \\ University of Cyprus, Cyprus \& King's College London \& MIT, UK
}

This article addresses certain key issues of the Greek sovereign debt crisis and its broader economic distress and growth implications for the Euro Area. It also offers a number of remedies, including growth indexed bonds, fiscal balances over the growth cycle, structural reforms, and the use of real option analysis in relevant public policy areas involving either inefficient or growth sectors of the economy.

Keywords: Greek sovereign debt; Eurozone financial crisis; GDP-linked bonds; structural reforms; real options

\footnotetext{
* Corresponding author: Lenos Trigeorgis, Bank of Cyprus Chair Professor of Finance, University of Cyprus, Kallipoleos 75, PO Box 20537, CY 1678 Nicosia, Cyprus; tel +357 22893605, fax+357 22895030, email lenos@ucy.ac.cy. The article is based on a synthesis and extension of ideas presented by the authors at a policy panel discussion held during the 19th Annual International Real Options Conference in Athens in June 2015. The discussions addressed the ongoing distressed situation in Greece and the broader goal of promoting growth in the Eurozone. We thank the conference participants for comments on aspects of this article. We particularly acknowledge the comments and contribution of one of the panelists, Peter Pope, on the section relating to the role of institutions and structural reforms.
}

(Multinational Finance Journal, 2018, vol. 22, no. 1/2, pp. 1-33)

(C) Multinational Finance Society, a nonprofit corporation. All rights reserved. 
Article history: Received: 27 December 2017, Received in final revised form: 1 July 2018, Accepted: 13 July 2018, Available online: 18 July 2019

\section{Introduction}

The high debt of the Greek public sector continues to feed the public policy debate. Despite fiscal measures, austerity and structural reforms and a debt haircut in 2012, the policy debate continues to revolve on how to deal with the Greek sovereign debt as it keeps raising fears and anxiety about slow economic growth or even distress. The 2018 International Monetary Fund (IMF) country report (table 1) shows that over the last decade the fiscal imbalance in Greece has continued unabated, reflected in economic decline (or stagnation) and a rising gross debt face value as a proportion of GDP, despite a moderate decline in the unemployment rate since 2013. IMF (2017) suggests that many of the IMF forecasts in the past have been too optimistic.

As distress and growth are central to the broader policy debate, the paper deals with related issues that are pertinent for the future of Greece and the Euro Area itself, the political economy of Greek debt sustainability, growth-linked bonds, balanced government budgets, structural reforms and public intangibles investment, as well as the role of real options analysis in public policy and debt renegotiation. Specifically, the article proposes four remedies: (1) linking government debt to economic growth ${ }^{1}$ so debt holders can benefit from less austerity, unless the EU institutions agree to substantial debt reduction as suggested by the IMF; (2) allowing for periodic fiscal imbalances reflecting capital expenditures promoting growth; (3) implementing structural reforms for improving economic efficiency and productivity; and (4) taking the perspective of real option analysis, e.g., for contraction or abandonment of increasingly inefficient sectors, or involving switching and growth options for those sectors that can help promote economic growth. The sections below reflect this reorganization perspective. They discuss each aspect in detail but have as unifying thread the discussion of issues deemed important for regaining stability and growth in a debt-ridden economy.

1. After this paper was written, this type of policy option was discussed among European lenders under the jargon name: "The French solution." 
Greek Sovereign Debt: Addressing Economic Distress \& Growth in the Euro Area 3

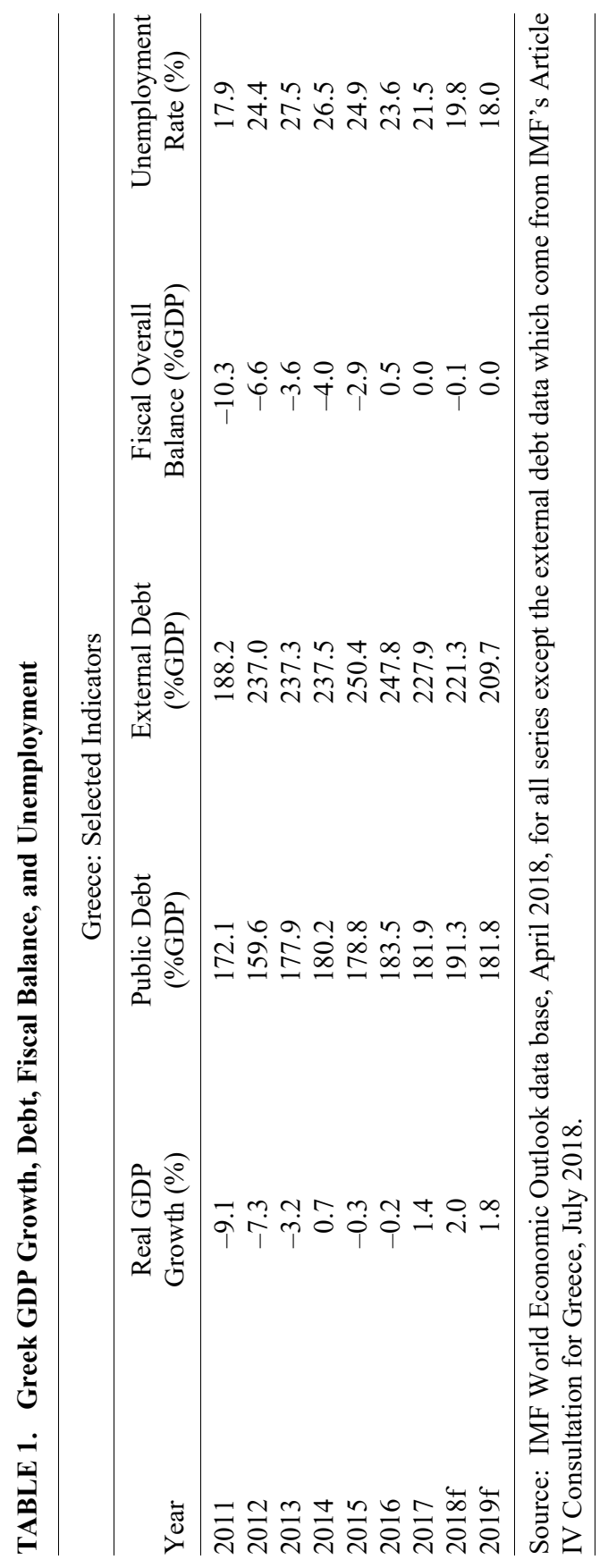


Section II reviews the profile of the Greek debt and the main events surrounding the Greek debt crisis. It argues that, following the 2012 debt haircut and reprofiling, the main impediment to growth is not so much the size of the public debt, but rather the lack of effective policy measures and of structural reforms for correcting the major imbalances in the economy. While the size of the Greek debt raises questions about its sustainability (Reinhart and Rogoff, 2010), its particular characteristics (grace period, interest rate, debt maturity and official sector ownership) render it less problematic as its present value is significantly less than its face value (Schumacher and di Mauro, 2015; Landon, 2015; Serafeim, 2015). It thus remains a constraint to growth only as far as Greece lacks market credibility and fails to effectively implement structural reforms needed to achieve sustainability and promote long-term growth.

Section III discusses growth-linked bonds which might serve as a useful financial instrument in distress economies to help service their debt, link interest payments to future economic growth and help alleviate growth restraints. For such instruments to succeed requires a disciplined but flexible long-term policy in balancing the budget as well as structural reforms for attaining an efficient operation of the economy and market institutions. Suggestions are made for avoiding pro-cyclical balanced budgets and investment policies and attaining more stabilizing macroeconomic policies.

On the notion of balanced budgets, Section IV further highlights the need to distinguish between operating and capital budgets as operating deficits need to be balanced in the short run, while capital budgets may be optimally balanced over a longer period. A golden rule must aim to attain inter-generational fairness on debt repayments. Therefore, it is acceptable to borrow now to make capital improvements in the economy while maintaining a balanced budget on social spending policies, which do not contribute to capital value creation. Naturally there is a challenge regarding the credibility of consecutive governments and politicians to keep the budget balanced in the long-term, safeguarding inter-generational balance and time consistency. These issues present dilemmas and opportunities for further research in the public policy sphere.

Structural reforms and public intangibles investments are necessary complements for keeping public debt sustainable. Section V maintains that needed reforms should span the well-functioning of public institutions and markets, an appropriate legal framework, law enforcement and regulation, prudent governance, investor protection, tax enforcement, and a supportive entrepreneurial culture. These 
elements should interact in a way that supports EU's inclusive and sustainable economic growth policy. Progress on this front in Greece has been admittedly slow and difficult. If these reforms were enacted well in advance of crisis conditions, much of the austerity measures might have been unwarranted or much less painful. This again brings forth the issue of politicians' horizons.

An important item in the growth agenda relates to conditions, impediments and caveats concerning policy effectiveness and enforceability. Effectiveness might be limited due to incomplete contracting issues (Hart and Moore, 1985). Possible remedies include creditors' administration and improving sovereign management and program ownership, although the risk remains for fiscal policy responses to replace needed structural reforms. Another concern arises from possible insufficient investor demand for debt relief instruments due to their longer duration and risk, which also increases the cost of sovereign debt. Incentive problems may also emerge as citizens lack effective tools for ensuring equitable inter-generational sharing of the costs of servicing the debt and matching costs and benefits. Further, capital markets cannot ensure a sustainable debt burden across future generations.

Finally, the article discusses the role of real options analysis in this debate and in public policy. Section VI specifically addresses how real options could be applied in sovereign debt renegotiation. It also offers potentially a more objective analysis for public policy discussions away from economic and political biases. In this context, it is important to understand the different players' objectives, strategies and consequences of various actions for the various parties involved. Real options in this setting include defer options in debt renegotiations (avoiding certain costly exit consequences), growth options generated by investment in public infrastructure capacity, contraction options such as public-sector downsizing, exit or abandonment options as well as switch options involving changing economic or operating conditions with a different mix of costs and benefits. Strategic real options may further be envisaged based on a combination of game theory and real options in a two-party borrower-lender context, aiming at sharing opportunities and risks. Real option models can further consider the appropriate capacity for infrastructure projects and the mix of resources over time. Entry/exit, switching and capacity choice options also seem to be relevant here. Public policy considerations include appropriate taxes, subsidies, abatement policies, investment incentives, and public and private management in various economic sectors. 


\section{Size and Features of Greek Public Debt: What Went Wrong and Why?}

Table 2 below describes the size and composition of Greek public debt at the end of March 2018. The budgetary central government debt amounted to $€ 343$.7bn and was held primarily by the official sector, as $66.2 \%$ or $€ 227.7$ bn was held by the European Monetary Union (EMU) countries, the European Stability Mechanism (ESM) and the European Financial Stability Facility (EFSF), 3.0\% or $€ 10.0$ bn by the IMF, and $3.7 \%$ or $€ 12.9$ bn by the European Central Bank (ECB) and the EMU national central banks. The notes in table 2 provide further details on the debt components.

The nominal size of Greek debt relative to the size of the economy is quite large. Given an expected level of GDP of $€ 183 \mathrm{bn}$ in 2018, the central government's debt is $189.9 \%$ of GDP. ${ }^{2}$ This is the largest percentage among developed countries except Japan. Yet through a variety of concessions offered by the lenders over the 2010-2018 period, the debt has some favorable characteristics, leading to a reduced burden in present value terms (Schumacher and di Mauro, 2015). These characteristics include low interest rates, a grace period until 2032 for the interest payments to the EFSF loans, and an extension to the EFSF maturities. Table 3 presents the maturity profile of debt as of the end of March 2018.

\section{A. The Debate on Debt Sustainability and the PSI}

Greek public debt sustainability has been at the core of an ongoing debate since the beginning of the Greek crisis. At that time most of the Greek debt was held by European and Greek banks, raising the fear of a contagion spreading into Europe from a possible Greek default (Gogos, Monokroussos and Stamatiou, 2015). The sustainability controversy began in May 2010, when EMU countries together with the IMF moved to rescue Greece from impending default. The assumptions about future Greek growth prospects that underlay the rescue deal were very optimistic and rendered the debt sustainable (IMF, 2010a; IMF,

2. In September 2017, the General Government's debt was a bit smaller, at approximately $€ 310.8 \mathrm{bn}$ or $175 \%$ of GDP. See the notes of table 2 . The Public (General Government) Debt (Maastricht definition) differs from the Budgetary Central Government Debt by the amount of intra-sectoral debt holdings and other European System of Accounts (ESA) adjustments. 
Greek Sovereign Debt: Addressing Economic Distress \& Growth in the Euro Area

TABLE 2. Composition of Greek Public Debt (€bn) as of March 2018

\begin{tabular}{lcc}
\hline & Amount $(€ \mathrm{bn})$ & Share of Total \\
\hline EU/EFSF/ESM & 227.7 & $66.2 \%$ \\
IMF & 10.4 & $3.0 \%$ \\
ECB/NCBs & 12.9 & $3.7 \%$ \\
T-bills \& Repos & 36.8 & $10.7 \%$ \\
Pre PSI Bonds - Holdouts & 0.5 & $0.2 \%$ \\
Post PSI bonds & 40.0 & $11.6 \%$ \\
Other & 15.4 & $4.5 \%$ \\
Total & 343.7 & $100 \%$ \\
\hline
\end{tabular}

Source: Hellenic Republic, Public Debt Management Office.

\section{Notes:}

a Some entities that belong to the General Government but not the Central government, like public pension funds, local governments or public companies, either have debt of their own (adding to the stock of General Government debt) or hold central government securities (subtracting from the stock of General Government debt). It turns out the General Government Debt is always below the above Budgetary Central Government Debt. For example at the end of 2017 The General Government Debt was at $€ 317.4 \mathrm{bn}$ while the Budgetary Central Government Debt stood at $€ 328.7 \mathrm{bn}$.

b The EU/EFSF/ESM debt is composed of $€ 52.9 \mathrm{bn}$ of the early 2010 individual bilateral EMU country loans to Greece (often referred as Government Loan Facility or GLF), the subsequent $€ 130.9 \mathrm{bn}$ loans of the European Financial Stability Facility (the pre-cursor to ESM), and the more recent $€ 43$.9bn of European Stability Mechanism loans.

c The ECB/NCBs loans are composed of face value of $€ 9.5 \mathrm{bn}$ of Greek Government bonds held by the European Central Bank through its Securities Markets Program and of face value of $€ 3.3 \mathrm{bn}$ of earlier investments in Greek Government bonds by individual central banks of different EMU countries.

$\mathrm{d}$ T-bills amount to $€ 14.33 \mathrm{bn}$ as their issuance is restricted by a cap of $€ 15.0 \mathrm{bn}$. Repurchase Agreements fluctuate over time and are performed through the use of special T-bill issuance as collateral. At the end of September 2017, the outstanding amount of repos was $€ 22.5 \mathrm{bn}$.

e The Pre-PSI bonds are bonds issued in earlier times, which were not exchanged in 2012 for new bonds as their holders refused to exchange them (they are the "hold-outs" in the PSI process), and have not yet matured.

$\mathrm{f}$ Post-PSI bonds are free floating bonds and include an outstanding face value amount of $€ 29$.6bn from the PSI transaction itself plus a face value amount of $€ 10.4 \mathrm{bn}$ of new bonds, issued in 2014, 2017 and 2018. The amount of $€ 29.6 \mathrm{bn}$ consists of 20 bonds with annual maturities from March 2023 to March 2042 and with step-up coupons over time. Their outstanding amount is the result of the PSI swap of old securities through the Private Sector Involvement of February-March 2012 and the Debt Buy-back of December 2012. A large amount from this set of 20 bonds ( $€ 25.8 \mathrm{bn}$ or circa $85.6 \%$ ) was further swapped through a public offer in November-December 2017 into a smaller set of 5 bonds, with five maturities in January of 2023, 2028, 2033, 2037, and 2042 and with fixed coupon rates of $3.50 \%, 3.75 \%, 3.90 \%, 4.00 \%$ and $4.20 \%$ respectively.

$\mathrm{g}$ "Other" includes European Investment Bank Loans (€8.0bn), Bank of Greece Bilateral Loans (€2.8bn), etc. 
TABLE 3. Maturity Profile and Face Value of Greek Debt ( $€ b n)$ as of March 2018

\begin{tabular}{|c|c|c|c|c|c|}
\hline Year & T-bills & Repos & Bonds & Loans & Total \\
\hline 2018 & 13322 & 22504 & 1870 & 2022 & 39718 \\
\hline 2019 & 1011 & & 8781 & 2971 & 12763 \\
\hline 2020 & & & 1366 & 3652 & 5018 \\
\hline 2021 & & & 0 & 5093 & 5093 \\
\hline 2022 & & & 4312 & 5536 & 9848 \\
\hline 2023 & & & 4906 & 7309 & 12215 \\
\hline 2024 & & & 1751 & 5934 & 7685 \\
\hline 2025 & & & 3484 & 5563 & 9047 \\
\hline 2026 & & & 1149 & 5568 & 6718 \\
\hline 2027 & & & 161 & 6538 & 6699 \\
\hline 2028 & & & 6346 & 5850 & 12196 \\
\hline 2029 & & & 165 & 5428 & 5593 \\
\hline 2030 & & & 253 & 6045 & 6299 \\
\hline 2031 & & & 129 & 5796 & 5925 \\
\hline 2032 & & & 126 & 6001 & 6127 \\
\hline 2033 & & & 6238 & 5741 & 11979 \\
\hline 2034 & & & 468 & 6417 & 6885 \\
\hline 2035 & & & 144 & 6434 & 6578 \\
\hline 2036 & & & 166 & 6459 & 6625 \\
\hline 2037 & & & 5084 & 6474 & 11558 \\
\hline 2038 & & & 147 & 5889 & 6036 \\
\hline 2039 & & & 135 & 5907 & 6042 \\
\hline 2040 & & & 142 & 5218 & 5360 \\
\hline 2041 & & & 137 & 3871 & 4008 \\
\hline 2042 & & & 4768 & 3312 & 8080 \\
\hline 2043 & & & 0 & 4756 & 4756 \\
\hline 2044 & & & 0 & 4777 & 4777 \\
\hline 2045 & & & 0 & 5381 & 5381 \\
\hline 2046 & & & 0 & 5802 & 5802 \\
\hline 2047 & & & 0 & 10073 & 10073 \\
\hline 2048 & & & 0 & 6894 & 6894 \\
\hline 2049 & & & 0 & 7965 & 7965 \\
\hline 2050 & & & 0 & 8489 & 8489 \\
\hline 2051 & & & 0 & 9388 & 9388 \\
\hline 2052 & & & 0 & 9533 & 9533 \\
\hline 2053 & & & 0 & 9854 & 9854 \\
\hline 2054 & & & 0 & 10193 & 10193 \\
\hline 2055 & & & 0 & 6472 & 6472 \\
\hline 2056 & & & 0 & 9478 & 9478 \\
\hline 2057 & & & 1162 & 2246 & 3408 \\
\hline 2058 & & & 0 & 2252 & 2252 \\
\hline 2059 & & & 0 & 2260 & 2260 \\
\hline 2060 & & & 0 & 2670 & 2670 \\
\hline Total & 14333 & 22504 & 53392 & 253511 & 343740 \\
\hline
\end{tabular}

Source: Hellenic Republic, Public Debt Management Office and Public Debt. 
2010b; IMF, 2012b; Blanchard and Leigh, 2013). Yet from early 2010 on, the IMF analysis had shown that significant uncertainties remained as to whether the debt was sustainable in the medium term (IMF, 2010a). Based on such an assessment, the IMF would normally not have lent to Greece without a prior debt haircut. But it appears that broader international considerations dominated the IMF decision, mainly the possibility of contagion that a Greek debt haircut might bring to the rest of the Euro Area, possibly leading to an increase in European interest rates and a global growth contraction.

By mid-2011, it had become evident the Greek economy would not recover anytime soon and debt relief was unavoidable. European politicians pondered ways to relieve the debt burden of Greece (Council of the European Union, 2011). ${ }^{3}$ A sizeable debt haircut eventually took place in March 2012, which came under the name "Private Sector Involvement" or PSI and amounted to $53.5 \%$ of the nominal value of bonds and loans to the Greek State. Approximately €200bn worth of bonds were exchanged for "cash" bonds (with up to two-year maturity) representing $15 \%$ of the old face value, plus new bonds were issued worth $31.5 \%$ of the face value. These had very low interest rates and longer maturities, ranging from 10 to 30 years (maturing every March from 2023 to 2042).

There was also an extra detachable option feature - a GDP warrant, callable from 2020 on - on the value of the new post-PSI bonds, conditioned on the rate of future economic growth (Bank of Greece, 2012). If both nominal and real GDP were to exceed a specified target path, which was roughly in line with the IMF's medium and long-term growth projections for Greece, there would be an extra payment stream of up to one percentage point of the face value (see tables A1 and A2 and analysis in Zettelmeyer, Trebesch and Gulati (2013)).

The PSI decision of February 2012 was accompanied by a simultaneous agreement to continue lending to Greece at favorable (below-market) rates until the end of $2014 .{ }^{4}$ At that time the expectation was that Greece would be able to tap the markets in 2015 and that its

3. Extraordinary summit meeting on Greece, July 21, 2011.

http://www.consilium.europa.eu/media/21426/20110721-statement-by-the-heads-of-stateor-government-of-the-euro-area-and-eu-institutions-en.pdf

4. This was the Second Economic Adjustment Program (European Commission, 2012), or the second attempt at a Greek rescue. The Greek government received a second loan and committed to implement a series of structural reforms in the government, the financial sector, and other sectors of the economy. 
debt would slowly decline to $120 \%$ of GDP by year 2020 . Yet a few months later it became evident that the recession was a lot worse than expected in early 2012 and the original plan would not materialize without additional help. Additional debt relief measures were offered in November 2012, under the term "Official Sector Involvement" or OSI.

OSI included lower interest rates on future loan disbursements, the return of profits made on Greek government bonds by the ECB and national EMU central banks, and further maturity extensions. In addition, the Greek government bought back some of the outstanding debt, which was trading at a considerable discount, further reducing its face value. Also, in November 2012, the Greek government was given a promise of further future debt relief, assuming fiscal consolidation succeeded in generating primary surpluses and structural reforms were completed as detailed in the Economic Adjustment Program (Eurogroup, 2012).

Since the PSI conclusion and up to the end of 2013, the IMF continued to express concern about the risks surrounding Greek public debt sustainability. However, by the summer of 2014, the IMF appeared increasingly optimistic about Greek debt sustainability and dropped its previous cautionary remarks. ${ }^{5}$

\section{B. Proposal for Additional Debt Relief}

By the fall of 2014 the fiscal consolidation had led to small government primary surpluses and the Second Economic Adjustment Program of 2012-2014 was close to being concluded. The Greek government proposed a set of measures aimed to provide further debt relief (Strupczewski, 2014). ${ }^{6}$ Those measures included fixing interest rates

5. On June 26, 2015, it made the following statement: "At the last review in May 2014, Greece's public debt was assessed to be getting back on a path toward sustainability, though it remained highly vulnerable to shocks. By late summer 2014, with interest rates having declined further, it appeared that no further debt relief would have been needed under the November 2012 framework, if the program were to have been implemented as agreed...." The statement in quotes suggests that in mid-2014 the IMF thought that Greece needed no extra help to make its debt sustainable.

6. This official Greek proposal aimed at setting the agenda for a fuller and more detailed discussion later, in 2015. Yet it never got off the ground because the Program was not concluded in December 2014. At the Eurogroup meeting of December 8, 2014, the European Union (EU) Commission stated that Greece had fulfilled all the requirements to conclude the Review. The EU Commission gave its approval of the so-called "Hardouvelis 
for a longer period to take advantage of prevailing global low rates. In terms of maturity extensions, it proposed that the EFSF and Greek Loan Facility (GLF) loans could be extended up to 50 years. Finally, the proposal sought to obtain an extension of the grace period for the EFSF interest deferral to 2030, a time when the Debt-to-GDP ratio was to drop below $80 \%$. This could also help avoid a liquidity crunch in 2022 when large payments were due. ${ }^{7}$

Many alternative ideas were also being discussed at the time, even though they never became official proposals, partly because of political constraints and partly due to the presence of moral hazard. ${ }^{8}$ These included ideas involving debt-for-equity swaps, contingent interest payments or maturity extensions contingent on the size of the fiscal balance, the rate of economic growth or the pace of structural reforms. In the end, the fall 2014 proposal for further debt relief was stopped short by the outcome of previously unscheduled national elections, which prevented the 2 nd adjustment program from reaching conclusion.

\section{Second Greek Crisis and Third Rescue Program (2015-2018)}

The January 2015 national elections brought a new coalition government, led by the leftist party of SYRIZA, which had campaigned on a promise to deliver a nominal debt haircut. ${ }^{9}$ The new government

e-mail," a package of reform and strict fiscal measures intended to result in a primary fiscal balance of $3 \%$ of GDP in 2015. However, the IMF and the ECB did not indicate this package was satisfactory to them. A two-month extension of the Program to the end of February 2015 was given at the Eurogroup of December 8th 2014 (Eurogroup, 2014; ESM, 2014).

7. Fourth, a sweetener interest rate deferral on $€ 96.1 \mathrm{bn}$ coming from the Master Financial and Administrative Framework (FAFA), €29.7bn from the PSI Facility (Sweetener) and $€ 4.9 \mathrm{bn}$ from the Accrued Interest Facility could bring further annual savings of $€ 550 \mathrm{bn}$.

8. Before the final draft of the Second Economic Adjustment Program 2012-2014, when one of us served as the Chief Economic Adviser to the Greek Prime Minister, the Greek side had proposed to condition the size of the fiscal balance on the rate of economic growth during the life of the new program. Lenders were not willing to commit to this proposal on paper, yet later in 2012 when economic growth was lower than the one predicted in the Program, they relaxed the fiscal targets and provided substantial debt relief, the OSI.

9. This was promised despite the fact that most Greek public debt was already in official hands (EMU countries, IMF, ECB) and the free floating amount was governed by English law. See the notes of table 2 for the face value amounts and their definitions. Chrysoloras (2014) provides an outline of SYRIZA's Program announced in Thessaloniki in September 2014. The Program outlined the features of the debt haircut that a SYRIZA government would ask from official creditors. Later on, the President of the European 
followed an adversarial negotiating strategy with the lenders, which resulted in political isolation and loss of credibility. European and IMF loan disbursements were interrupted and public liquidity was stretched. The government kept postponing payments to its service providers, failed to deliver the June IMF installment, and its financing problem was increasingly becoming acute. An ECB installment was due in July. Meanwhile bank stock prices collapsed and the fear of GREXIT spread among Greek households and international investors. Greek households started withdrawing their bank deposits, which eventually led to the implementation of capital controls.

The Greek economy, which had reached positive real growth by end 2014, reversed course. ${ }^{10}$ The Greek government, after risking GREXIT through pushing for a referendum, ended up signing a third rescue package in August 2015. The Third Economic Adjustment Program of 2015-2018 (ESM, 2015) provided lending for three additional years. ${ }^{11}$ The government external debt as a percent of GDP continued to rise and the IMF reversed its earlier positive (2014) outlook on public debt sustainability (IMF, 2015a; IMF, 2015b). ${ }^{12}$ Since then, the IMF has called publicly for additional debt relief and smaller future primary surplus targets in order to allow the economy to begin growing again.

A later decision on Greek public debt took place at the Eurogroup meeting of May 2016. A set of short-term, medium-term and long-term measures were then decided. The medium and long-term measures were

Commission, Jean Claude Juncker, presented details on the negotiations with the Greek government prior to the referendum announcement of July 26th 2015 (Juncker, 2015). See also SYRIZA (2014).

10. For a timeline of the Greek debt crisis, refer to Meghir et al. (2016) and IEO (2016).

11. The third economic adjustment programme for Greece started on August 19, 2015 and is scheduled to run until August 20, 2018. The financial assistance of up to $€ 86$ bn is provided by the ESM. The participation of the IMF remains in question as of December 2017. For the details of the Program, see http://www.consilium.europa.eu/en/policies/financialassistance-eurozone-members/greece-programme/

12. On July 14,2015 , its main statement read as follows: "Greece's public debt has become highly unsustainable. This is due to the easing of policies during the last year, with the recent deterioration in the domestic macroeconomic and financial environment because of the closure of the banking system adding significantly to the adverse dynamics. The financing need through end-2018 is now estimated at Euro 85 billion and debt is expected to peak at close to 200 percent of GDP in the next two years, provided that there is an early agreement on a program. Greece's debt can now only be made sustainable through debt relief measures that go far beyond what Europe has been willing to consider so far." 
postponed until after the third adjustment program (in August 2018) and would be implemented only if needed to make the debt sustainable. The short-term measures began being implemented in 2017. They contained two major policies. First, the weighted average maturity of the EFSF loans (of $€ 130.9 \mathrm{bn}$ face value) was expanded from 28 years to 32.5 years. Second, ESM began a program on behalf of Greece of gradually swapping floating rate Greek debt for fixed rate debt of 30 years' maturity (ESM, 2017). The exact target amount of the swap had not been published as of mid 2018. ${ }^{13}$

Finally, in the June 2018 Eurogroup meeting, almost two months before the official end of the Third Rescue Programme, there was an agreement on the implementation of a series of medium term debt relief measures. ${ }^{14}$ These included a) the further extension of the interest and amortization of the loan received under the Second Economic Adjustment Programme for Greece, (b) the extension of the aforementioned loan's maximum weighted average maturity by 10 years (of approximately $€ 98$ billion), (c) the return of Securities Market Programme (SMP) Agreement on Net Financial Assets (ANFA) income equivalent amounts in order to be used for reducing gross financing needs and / or financing other agreed investments, and (d) the abolition of the step-up interest rate margin up to 2022. The last two measures (items (c) and (d)) are conditional on the implementation of a series of structural reforms in the context of the enhanced post programme surveillance of Greece for the period 2018-2023. The decision of the long term debt relief measures was postponed.

On the basis of the medium term debt relief measures and conditional on a very strict set of macroeconomic assumptions, gross public debt is expected at ca $80 \%$ of GDP in 2059 with gross financing needs below $15 \%$ of GDP in the medium term (up to 2035) and below $20 \%$ of GDP in the long term (between 2035 and 2060) (Bank of

13. Further, in November-December 2017, the Greek Public Debt Management Office made a public offer to exchange the set of twenty post-PSI bonds that matured from 2023 to 2042 for a smaller set of five bonds maturing over the same time span (see notes of table 2). The swap was successful as it attracted $85.6 \%$ of the old bonds. Since then liquidity has improved and bond yields have declined by close to 100 basis points.

14. For more information on the June 212018 decisions on the medium term debt relief measures and the post-programme relationship between Greece and its official creditors please refer to the following website: $\mathrm{http}$ ://www.consilium.europa.eu/en/press/press-releases/ 2018/06/22/eurogroup-statement-on-greece-22-june-2018/ 
Greece, 2018). ${ }^{15}$ Yet doubts on the sustainability of Greek debt beyond year 2032 remain.

With the above background, we next examine in more detail four suggested remedies: In section III, linking government debt to economic growth so debt holders benefit from less austerity; in section IV, allowing for periodic fiscal imbalances reflecting capital expenditures promoting growth; in section $\mathrm{V}$, promofting structural reforms for improving economic efficiency and productivity; and in section VI, proposing a research agenda using real option analysis for contraction or abandonment of increasingly inefficient sectors, and switching and growth options for sectors promoting economic growth.

\section{Growth Related Concerns in Europe}

We next consider three issues related to the broader theme of economic distress, sustainability and growth in Europe, namely, (a) economic growth-linked bonds, (b) whether government budgets of bailed-out countries should be balanced or should have a primary surplus, and (c) structural reforms and the role of public intangibles investment.

\section{A. Growth-linked bonds}

With respect to the issue of sustainability and growth, some EU politicians have advocated policies regarding the bailout of some troubled Eurozone countries that are likely to be self-defeating. They have insisted, in principle correctly, that troubled countries bring their finances to a sustainable path. However, the less able-to-pay the borrowers become, the tougher the repayment terms imposed, leading to a vicious cycle of further contraction.

Both sides may have meritorious arguments, but each focuses on a partial view of the complex and interactive issues involved. On one hand, as international creditors demand, structural reforms are needed to improve the effectiveness and functioning of public institutions and markets in order to facilitate long-term development and growth. Those who provide the credit rightfully also want to ensure that the debt is sustainable so they do not have to put up more money in the future. But

15. For the shift of interest from Debt Sustainability in levels (stock) to Gross Financing Needs (flow) please refer to Gabriele, Carmine, et al. (2017). 
it is also commonly understood (though not always publicly admitted in EU policy circles) that there is little chance Greece will be able to repay its public debt in full anytime soon. It simply does not have the capability. The creditors have argued that the borrower (Greek state) has been irresponsible and threatened with GREXIT. But one may counter-argue that behind each irresponsible borrower there is an irresponsible lender (the public EU sector, the ECB and the IMF in this case) who, perhaps for political reasons, has refused to recognize losses due to other constraints, poor judgment and practices. But, as when international creditors recapitalize banks when they get into trouble, by lowering their debt in exchange for more (forced) equity, perhaps they should also consider doing the same when they bail out a nation by taking an equity position in that nation's future so the interests of the two are more closely aligned.

One way to do this is to tie the future interest payments paid on rescue loans to the growth of that nation's economy. When the economy is in recession, as the Greek economy has been for the last six years or so, the debt interest burden will be lower, helping the country to recover and boost growth; when economic growth would pick up, GDP-linked interest payments will be higher precisely when the country can afford it.

Suppose, for example, that Greece's steady-state GDP growth is 3\% and that the fixed interest rate on EU rescue loans is $2 \%$. Instead of a fixed rate loan, the country could issue bonds paying interest at its GDP growth minus $1 \%$ (the difference between the average growth rate of $3 \%$ and the EU bailout rate of $2 \%) .{ }^{16}$ If GDP growth next year is $0 \%$, lenders would pay the bailed-out country $1 \%$, providing it with some relief in hard times. But if, say, 5-10 years later, the GDP growth is 5\%, lenders would instead receive $4 \%$. In essence, during recession EU lenders will provide insurance and an interest subsidy to troubled Eurozone members, helping them pull themselves up, in exchange for higher growth-induced returns during good times. If a country is forced to suffer GDP contraction as a result of imposed austerity policies (e.g., as happened to Greece with -6.5\% GDP annual contraction in 2011-13) and the EU Institutions believe in the rightfulness of austerity, they

16. A simple IMF model regarding a debt-stabilizing primary fiscal balance (DSPFB) is: (from footnote 7 of IMF, 2017): DSPFB $=(\mathrm{r}-\mathrm{g}) *($ Debt/GDP). If the growth indexed interest rate is $\mathrm{g}-1 \%$, the DSPFB could be $(-1 \%)$ that is slightly negative, indicating that continuing the fiscal imbalances would not necessarily result in an exploding Debt/GDP as forecast by the IMF (2017). 
should share that burden with the patient country. Increased interest obligations in good times might also discourage rescued governments from sliding back into bad habits.

Certain investor safeguards are needed of course. Bonds should not be callable when growth exceeds a threshold (as in Bulgaria) because that would eliminate investors' upside and kill their incentives. Protection against manipulation of reported GDP growth statistics by the country in trouble is also an understandable concern. Countries with resource-driven growth prospects, such as Cyprus and potentially Greece, could consider making these bonds convertible into the relevant natural resources or commodities. Cyprus, for instance, could make its bonds convertible into natural gas to reduce the repayment obligation or in exchange for better loan terms. The conversion option into natural gas would provide lenders and investors more assurance about the loan's upside potential. Gas prices are less subject to manipulation or mismanagement by governments than GDP growth statistics, gas revenues, government budgets or the future state of the domestic economy. In effect, the gas-linked option collateralizes the loan with gas, lowering its riskiness.

Who might want to buy these bonds? One attraction to investors is that they offer an equity-like ownership position on a nation's growth prospects. Evidence from financial markets confirms that investors are willing to accept lower average returns in the short-term in exchange for a chance at high future growth potential. Many important businesses, such as venture capital, pharmaceuticals or the movie industry, owe their success to actively managing such portfolios of (low-probability) high growth prospects. GDP-linked (especially commodity-convertible) bonds would provide broader benefits to the global financial system. By helping reduce the risk of sovereign defaults and contagion effects, they might strengthen EU stability and the global financial system. They might also offer a way for rich but low-growth EU countries to obtain a stake in countries currently in trouble, as a fair exchange for their support to recovery and realization of their growth potential.

Many types of institutional investors might potentially be attracted. Sovereign and hedge funds might be natural customers. Pension and insurance funds could also take an interest. These investors are already familiar with indexed bonds protecting returns from price inflation. But inflation-linked bonds offer little upside exposure to economic expansion. Bonds linked to nominal GDP growth offer both benefits in a single package. 


\section{B. (Un)balanced budgets}

Turning to the topic of balanced budgets (or imposed primary surpluses) and related macroeconomic policy implications, there seems to be a need to limit boom and bust cycles from pro-cyclical policies. Use of tight annual budgets by firms or governments (or imposed by the European Institutions and the IMF) that are inflexibly "balanced" or budgets that are driven by free cash flow or effectively by last year's revenue are pro-cyclical. If last year was good there is a larger budget and more real investment; but following down years or at times of austerity, budgets are reduced and investment/development is cut, causing more contraction. Such pro-cyclical budget and investment policies lead to boom and bust cycles and more social suffering. There is a clear need for more stabilizing macroeconomic policies. These, for example, might include (1) 5-year budget averaging requiring governments to balance their budget only in their last year in power (effectively presenting a balanced budget and a fair slate to the next government); (2) GDP-linked bonds as discussed above for Eurozone or emerging markets; (3) lower, rather than higher, tax rates in contraction/austerity periods (i.e., a dual tax regime system).

A real options (switching) perspective under conditions of uncertainty would bring natural hesitation (a "hysteresis", delay or lag in carrying out a change until it is clearer that the change in GDP is permanent), effectively resulting in smoothing or mean-reversion rather than momentum or pro-cyclical pressures. For example, when firms or governments are (almost) out of recession but with unclear trends and uncertainty looming, they are better off using flexible, part-time or contingent employees and engaging in more flexible outsourcing activities that allow more adaptation and reversing a decision. Thus, real options thinking and related policies to encourage growth in Europe would provide a natural antidote to current pro-cyclical austerity EU policies. These are discussed further in the last section.

\section{Structural reforms and public intangibles investment}

In addressing development and growth, the issue of structural reforms and public intangibles investment should naturally be taken into account. The previous suggestions on GDP-linked bonds (perhaps backed by some natural asset of the nation) and medium-term budget flexibility to work effectively presuppose well-functioning public 
institutions and markets for goods, labor, capital and credit (banking and financial system). This includes an appropriate legal framework, law enforcement and regulation, prudent governance, financial reporting transparency, investor protection and tax enforcement, public sector efficiency and containment of corruption and entrenched professional cartels - and, not least, a supportive business/entrepreneurial culture. These are part of what can be viewed as Infrastructural (societal/national) Public Intangibles. From this perspective, the international creditors rightfully put pressure on the Greek government to bring about positive changes in these important areas. Indeed, a nation or its government may potentially have negative public intangibles (i.e., intangible liabilities), for example, low credibility or a poor reputation of a bureaucratic and/or corrupt state, lax public order or tax collection, powerful trade unions or entrenched professional cartels. Thus, the issue of credibility is integral to the effective functioning of public sector institutions and the markets. In examining the net impact of austerity policies and structural reforms, one should consider not only the adverse impact of fiscal cuts but also the potentially beneficial impact on public sector efficiency.

Infrastructural public intangibles include public health, basic education and training; social cohesion and inclusion/participation (e.g., low social and economic disparities, low unemployment, particularly youth unemployment). Since most of the Greek government debt is held by EU institutions, converting past debt into growth-linked debt would be consistent with the idea that economic growth and stability are a suitable objective for Greece. The notion of inclusive and sustainable economic growth is central to Europe's 2020 strategy. Inclusiveness means that policy makers should take into account the whole spectrum of social fabric in their economic considerations and the feedback loops in the overall socio-economic system. Sustainability requires consideration of the interests and claims of the community, while growth also encompasses innovation, knowledge and learning. Collectively, they aim to attain a delicate balance between long-term economic performance and societal objectives, such as cohesion, employment, participation and inclusion, prosperity, the environment, and citizen well-being.

The extent to which structural reforms and public sector intangible investments enhance macro-economic performance and promote societal objectives is currently debated across Europe. The issues are complex and interdependent, and a balanced approach that recognizes 
these interdependencies is needed. There is a need for a more holistic understanding of how structural reforms and public intangibles interact to shape long-term economic growth and well-being in Europe. There is a pressing need to objectively assess the lasting value of structural reforms and intangible investments at the business and national levels and guide policy decisions in an informed manner. We need to identify complementarity and substitutability effects among different types of public intangibles and the ways they affect socio-economic performance; point to regulatory aids and/or impediments in transforming public expenditures to intangible investment; help develop methodologies to improve the measurement and quality of data in the National Accounts; produce policy tools and guidelines about ways forward at the national and the EU level. We also need in-depth analysis of comparative data about public intangible investments and the impact of austerity policies and structural reforms in EU countries to help assess their net impact on real wealth and the EU ecosystem.

Supporting the idea of GDP-linked bonds, taking a longer-term (e.g., 5 -year) perspective on balancing government budgets of bailed-out countries and recognizing the role of reforms and broader public intangibles investment for long-term economic growth and social prosperity could mark an important inflection point for the Eurozone. It is worth considering solutions that allow countries in difficulty to borrow, implement structural reforms and invest in public intangibles against a more promising future rather than condemning them to years of stagnation.

\section{Balanced Budgets and the Golden Rule in Sovereign Debt}

In line with the above, a key question is when to run a deficit and hence require financing by public debt. Here we suggest that deficits should be of a persistent nature if only to fund capital or infrastructure-type projects that will benefit those who are paying off the debt. While governments typically incur public debt to cover budget deficits, there are times when a budget deficit makes sense and times when a surplus might make more sense. Public debt is often of sufficiently long maturity that it is more likely to be paid off by future generations, so we may find some social policy guidance by considering Overlapping Generations (OLG) models. One rule that is often considered in these models is the Golden Rule, which says: "Do unto future generations as 
you would hope that previous generations did unto you". This rule is designed to maximize consumption over time. One approach to achieving this Golden Rule is to borrow money today to make capital improvements in the economy but run a balanced budget on social and operating spending (which do not generate capital value).

The money borrowed for capital improvements must be neutral in the sense that the present value of the benefits of the capital improvement, net of payments to amortize the debt, must be approximately zero. This is the public-sector version of the standard Net Present Value rule used in private-sector capital budgeting. The NPV rule can be readily extended to incorporate real option value in capital investments by requiring that capital expenditure optimally occurs when the value of the public benefits first rises to equal the (capital) costs plus the value of the real option to delay and resolve more uncertainty. Deficits on an operating budget should be incurred only because of or to absorb transitory shocks in GDP. These deficits should be offset by surpluses when the shocks are positive. So, over a longer period (say, of 5 to 10 years), the aggregate operating surplus/deficit should be approximately zero. Operating deficits are not self-correcting.

And herein lies a problem, particularly with local politics, but likely with global politics as well: citizens don't trust the politicians to get the 5 or 10-year aggregate surplus to zero because governments are typically elected for terms no longer than 5 years. The citizens thus anticipate that current politicians will pass the problems on to the next generation of politicians, and things can unravel. Moreover, the people don't trust the politicians to distinguish between the capital account and the operating account. Thus, the voters often support politicians who propose to constrain deficits with a "balanced budget" law. ${ }^{17}$ The above

17. In the US the National Association of State Budget Officers (NASBO, 2015) reports that 46 of the 50 US States have a balanced budget requirement. In 15 states, this is merely a statutory requirement so it is easy for a State Legislature to change it. The remaining 31 states have this balanced budget requirement in their constitution, which is harder to change. In 44 States, the Governor is required to submit a balanced budget to the State Legislature. In 41 States, the State Legislature is required to pass a balanced budget. The Fiscal Compact signed in 2012 by most countries in the European Union takes a different approach to balanced budget legislation. It requires that EU countries must have a "general budget deficit" that does not exceed $3.0 \%$ of gross domestic product (GDP). It also limits "structural deficits" (long-term non-cyclical deficits) to be less than $0.5 \%$ of GDP. This limit on structural deficits is similar to the notion that long-term budget deficits can only be justified if they generate capital benefits of a value comparable to the deficit costs that are imposed upon future generations. The Fiscal Compact is formally known as the Treaty on Stability, Coordination and Governance in the Economic and Monetary Union. 
creates the counterproductive result of pro-cyclical budgets, as noted earlier. When the economy is booming, and the private sector is bidding up the price of inputs for its capital expenditures, the government sees substantial tax revenues and proceeds to bid for the same high-priced and scarce resources. A countercyclical capital budget would instead be socially and financially more efficient.

These policies may go wrong for another reason: with a balanced budget law, politicians are tempted to overspend on capital projects when the economy is booming, because then they have more tax revenue to pay for projects. But in a booming economy capital construction projects are costlier, so they may not be able to complete or do them all. On the other hand, when the economy slows down and costs decline, these capital projects could actually be completed at lower cost. But the balanced budget provision would prevent them from being constructed. So effectively, a balanced budget provision forces the government to "buy high". It is fortunate that politicians can't sell these projects (except perhaps via privatizations), because otherwise the balanced-budget provision may have them "sell low" as well. This reaffirms the pro-cyclical nature of balanced budget policy discussed previously in Section III.

If governments could be disciplined to avoid these pro-cyclical and incentive-related problems, and the electorate would believe that government promises to achieve such a non-distorting policy are credible, then everything would be fine. Unfortunately, in politics things are not so ideal. First, it can be difficult to determine what benefit stream arises from a capital expenditure on roads, dams and other infrastructure projects. Measurement is even more problematic with respect to public debt incurred to fight a war. Governments typically finance a war by borrowing, but it is very difficult to measure the (expected) benefits of fighting a war, particularly when it is on foreign soil.

Another, potentially more serious, problem in implementing such rules about public debt and deficits is that there is generally a large difference between the shorter duration of a political party's period of government control and the much longer duration of the lives of citizens and voters who will be the ones to suffer from any suboptimal government decisions on the public debt and unbalanced budgets. Indeed, many voters might even be unborn at the time of the government's borrowing decision. This creates a substantial intergenerational governance problem, one that may be exacerbated by 
democratic processes that turn over governments so often that they rarely have to live out the consequences of their decisions. Often, newly-elected governments must endure the consequences of the decisions of previous governments.

It often takes a crisis for voters to realize that a government or policy change is needed. As Winston Churchill noted, "Never let a good crisis go to waste." Democracy provides the real option to the populace to change the government in power, but this is a repeated option and democracy does not provide a mechanism to ensure that the sequence of public real-option solutions is time consistent. Each temporal democratic solution may fail to solve the Bellman equation for a welfare function that extends inter-generationally.

Voters are not the only group with reason to be suspicious of government incentives and policies. Bondholders who buy the sovereign debt are also inherently suspicious of government promises when repayment is to be made by future generations. Securing the bond payment with some asset that can be used to pay off the debt is one approach to addressing this problem. The country can issue bonds backed by a commodity that is produced by that country's economy, as noted in Section III. Another approach is to secure the debt by some capital asset. This is often hard to do when the asset being financed is a bridge or a dam, since the creditor cannot repossess that asset. This is why developing countries often find that financing hydroelectric dams is much harder to accomplish than financing a gas-fired power generator that can be put on a barge or rail car, as the latter can be repossessed more easily.

\section{The Role of Institutions and Structural Reforms}

Plans for economic growth for a country like Greece cannot rely only on financial instruments tied to the country's growth (such as growth-linked bonds) and on budgetary rules as discussed above, but also critically depend on the efficiency and proper functioning of public and market institutions. While a focus on institutional strength and quality of markets might appear to be somewhat "off-piste", it is actually fundamental. If the institutional "plumbing system" is not up to specification, none of the other growth channels discussed earlier will likely work. Privatizations will be impossible or underpriced if we account for the expected dead-weight loss imposed by poor institutions 
and markets; infrastructure investors are not likely to be interested or may offer unfavorable terms; budgets will not be balanced because tax non-compliance is part of the equilibrium when politicians are not trusted by society to spend taxes efficiently. Therefore, the following are necessary preconditions for sustainable development:

1. Strong legal and economic institutions: Given a country's natural resources, a liquid capital market is important for economic growth. The quality of legal and economic institutions, investor protection regulation, and factors such as transparency and corruption containment have first order effects on market liquidity and desirable economic outcomes such as growth.

2. Well-functioning markets for goods, services, labor and capital: Robust markets follow from strong institutions, combined with economic policy and regulation decisions that are not captured by vested interests. Vested interests distort economic outcomes, moving them away from socially optimal outcomes.

3. A robust banking system: Well-functioning credit markets are critical for the country's economic development and growth. This requires effective banking regulation and enforcement of creditor rights, as well as reliable and transparent financial reporting by corporate borrowers. If the conditions for profitable lending to corporations and consumers are not there, banks will not contribute to the attainment of economic efficiency and growth.

Many of the structural reforms that have been demanded by the international creditors in programs addressing the Eurozone Crisis have the potential to contribute towards strengthening institutions and market effectiveness. This, in turn, can help promote growth via both public and private sector channels. A reading of the Greek Adjustment Program monitoring reports suggests that progress in many areas seems to have been incredibly slow and difficult. One can only imagine how different things might have been had a reform-minded government stepped up to the plate early in the crisis. Arguably many of the recent austerity measures would have been unnecessary had structural reforms happened early.

When the international institutions restructured Greek debt by swapping current debt obligations with long maturity debt with nearly zero-coupon payments until 2023, they effectively set up a crude form of growth-linked bonds. At the same time, by introducing structural reforms and linking future payments to them, they effectively introduced covenants creating renegotiation options, similar to what 
happens in private loan agreements in corporate finance due to incomplete contracting. However, the effectiveness of these "pseudo-covenants" is limited by politicians' short horizons and the lack of effective collateralization.

Similarly, growth-indexed bonds may not work from an ex ante contracting perspective. While debt-for-equity swaps might be an efficient bankruptcy resolution mechanism(Hart and Moore, 1998), the incentive and incomplete contracting problems might be challenging or even intractable. Arguably, the current approach, whereby creditor administration attempts to replace sovereign management of the economy, might be the only tenable mechanism capable of protecting creditor rights while establishing the possibility of recovery management. Of course, creditor administration can be far from perfect, for example when short-term fiscal policy responses are allowed to dominate structural reforms.

Another concern is whether there will be sufficient demand for equity-like sovereign securities. We do see quite complex financial engineering structures in corporate finance, so why not see indexed bonds in sovereign finance? It is possible that there might be insufficient investor demand for such instruments if investors whose liabilities are positively correlated with economic growth can hedge by investing in longer-duration growth stocks. Other investors would have to be compensated to accept risk because growth is risky, and this might lead to an overall increase in the cost of sovereign debt when index-linked. While recent (equity-based) asset pricing studies do suggest that an economic growth factor attracts a negative risk premium, term structure factor risk may attract positive risk premia. It is possible that index-linked debt will introduce such term structure risk that might raise volatility in an asset class that is presumably attractive relative to equities because of its lower volatility. Equity-like government securities will thus be priced like equities as they will have to compete with equities. An interesting related question is whether there is an optimal level of equity financing in an economy, conditional on its level of natural resources. How far away from optimal equity participation are countries like Greece? If effective ways of protecting investor and creditor rights can be found, to what extent are sovereign equity-type instruments and similar private equity arrangements (e.g., Cosco running Piraeus port) good substitutes for public equity, at least in the short run?

Finally, there may be major incentive problems underpinning 
economic growth and financing it through the state. Citizens do not have effective tools for ensuring equitable inter-generational sharing of the costs of servicing debt and matching costs and benefits. Nor do capital markets have effective mechanisms for ensuring that current government decisions create a sustainable debt burden across future generations.

In light of such political incentive problems, politicians should be encouraged to link their own compensation and wealth to long-term growth in the economy. How different might the world be if politicians were themselves compensated with growth-linked bonds that vest in 10-15 years (well beyond the length of a single political cycle)? The extent to which banks are prepared to lend to politicians against such bonds to finance their short-term consumption might then serve as a reliable indicator of the credibility of the policies being followed!

\section{Real Options in Public Policy and Sovereign Debt Renegotiation}

Real options in public policy can be viewed in three spheres: micro-economic (or industrial) policy, macro-economic policy, and sovereign debt policy. All of these involve important considerations for public policy makers, regulators, statesmen and administrators in developed countries, and are of critical value for countries in economic crisis, such as Greece. Below we briefly discuss some potential applications.

In the restructuring of the Greek economy, real option analysis could potentially contribute some worthwhile insights. Characteristic real options in this process include contraction and abandonment options to evaluate or restructure declining industries or inefficient sectors and switching and growth options to promote future growth activities. Contraction options involve downscaling, which might eventually be the case for the Greek public sector, with some reductions in operating costs and some deflation but possibly limited productivity improvements. Abandonment or exit involves changing entire economic or operating states, e.g., from active to completely idle, sometimes with large exit costs as in decommissioning nuclear power plants and sometimes with small costs as in scrapping old ships. Some predict severe exit costs for Greece, while others see devaluation advantages for the balance of trade. There are limited controlled economic experiments to assess these 
alternatives.

Growth options involve the generation of future +NPV projects that might benefit the country (and investors) and enhance the repayment capacity of the borrower. Switching options involve changing states with different mixes, lowest cost or highest benefit, or from active to idle, with the option to switch back potentially.

Is it possible for citizens or investors to use discounted Greek debt to pay taxes, consume tourist goods, or make inward investments? Revenue and pricing management uses such schemes frequently to fill capacity and discriminate among customer segments. Empty Greek hotels are a wasted asset, as is mass unemployment.

Certain strategic real options can be analyzed using a combination of game theory and real options, here in a two-party borrower-lender context with surely incomplete and asymmetric information. Is there a Win-Win solution? What if both parties would agree to share upside opportunities and downside risks, as in shared equity mortgages and many debt-equity exchanges in reorganizations and bankruptcy procedures, with both parties avoiding foreclosure costs? For agreeing to reduction of principal, lenders might be compensated with more share in equity market recovery, in more privatization proceeds, increased bad bank non-performing loan (NPL) recoveries, and share in the broader long-term benefits from reduced unemployment and higher economic growth.

These suggestions, of course, do not solve the EU dilemma of having a monetary union without a fiscal union, or achieving internal (rather than real exchange rate) deflation. Nor do they address the necessity of implementing public sector and other structural reforms discussed earlier. Further, sharing risk might have to also involve public (and politicians') salaries linked to indexes (like the GDP, or Debt/GDP) and other objectives deemed appropriate.

Real options might potentially offer a useful framework for more objective and far-sighted analysis, detached from economic and political bias. Calibration of the required inputs might be somewhat different from macro-economic tools, likely focusing on expected volatility of basic inputs and outputs, on the effects (sometimes surprising) of policy uncertainty, and on the consequences of certain moves in strategic real option games. This opens up a promising opportunity for a real options research agenda for public policy! 


\section{A. Micro-economic policy}

Most of the current applications of real options are focused on corporate finance or industrial structure. Extensions of immediate relevance for public policy in crisis countries are deferral, entry/exit, switching, and capacity choice options. Typically, real option models in these areas are prescriptive or predictive, given calibrated parameter values, indicating which types of firms should or will enter or exit first from a dynamic industry with changing input or output prices. Public policy issues, by analogy, might examine which firms, or indeed which industries, should be encouraged to enter or exit and when to do so, what mix of inputs/outputs or resources should be combined or altered over time, and what is the appropriate capacity in terms of size and staging for infrastructure investments, such as airports, roads, and rail, given uncertain demand (Lavrutich, Kort and Huisman, 2015).

Are multiple entry/exit decisions likely, or are only single, one-time switches feasible? Are the costs of entry and exit the same, constant (Tsekrekos and Yannacopoulos, 2016) or uncertain? As capacity is built for specific inputs (such as refineries or rail), what is the value of flexibility that should be encouraged as input prices change (e.g., as Greece has experienced in oil prices recently)? What is the national value of flexible production facilities (Dotis and Milonas, 2015), given alternative processes (Dias, Larguinho and Braumann, 2015), for particular industries? Many of these issues focus on national productivity and industrial structure.

What are appropriate charges, taxes or subsidies for pollution (and congestion) abatement policies? (Boomsma and Linnerud, 2015; Tsujimura, 2015). Public policies can further focus on incentives for encouraging early investment in low carbon energy sources, and on exit from polluting facilities. There are several complex alternative energy sources for Greece, considering future pipelines, offshore gas, and falling solar investment costs. Incentives for public and private management are also critical for sharing investment risks in these infrastructure projects. Public Private Partnership (PPP) structures and embedded government guarantees can be assessed using real options methods (Igrejas, Cordeiro, Brandão and Motta, 2015). Finally, there are typically sequential investments for national investments in R\&D and education, which are often very long term and built on the comparative advantage of nations (De Villemeur, Ruble and Versaevel, 2015). 


\section{B. Macro-economic policy}

Some of the prior real option models might also serve as fruitful additions or extensions for macro-economic policy. Unemployment, for example, might be viewed as a capacity planning and utilization decision, constrained by labor policies (Meier and Mecikovsky, 2015). An idle work force can be a wasting asset or can be turned into a growth opportunity. Fiscal balance is the residual of debt management, and bears analogies with the cash flow, investment, dividends and debt management policies of corporations (Koussis, Martzoukos and Trigeorgis, 2017). What are the appropriate incentives for various players, such as citizens as principals or statesmen as agents, or sovereign debt holders including central governments as residual balancing institutions? ${ }^{18}$

When is the right time or right conditions to enter or exit a currency union (Dias, Larguinho and Braumann, 2015)? Can such entry/exit decisions be temporary or be repeated multiple times, or are only single switches politically feasible given the needed trust requirements and precedent/signaling constraints? Would a European currency union allow central governments to serve as residual monetary-fiscal balancing institutions, in combination with conditional policies regarding national fiscal operations?

\section{Sovereign debt policy}

Another promising agenda concerns the role of real options in sovereign debt renegotiation. What are the objectives and consequences of the actions of different parties involved? What insights and predictions are plausible in calibrating such real option models for a country like Greece? Is the assumption of ability to repay (which enables the generation and holding of some of these real options) valid? Sovereign obligations in many cases can be seen as renegotiable debt, with both lenders and sovereign nations being involved in strategic real option games similar to those with mortgage lenders and borrowers (Flanagan and Paxson, 2015). Who are the players, what are their strategic actions and what are the equilibrium consequences? Several potentially

18. The above authors may have different opinions on whether their models can be adapted for public policies, and on what parameter values would need to be calibrated for such applications. 
instructive case studies seem quite relevant for sovereign borrowers and lending institutions.

\section{Concluding Remarks}

The Greek crisis, which began in late 2009 at a time when the international financial crisis was tapering off, has threatened the unraveling of the European Monetary Union and has, consequently, triggered a major overhaul in EMU policies and institutions. The creation of the European Stability Mechanism was one such outcome. The push for a closer banking union was another. Yet, Greece, the first country to enter into a crisis, by the end of 2017 is the only EMU country still remaining under a rescue program. The details of an eventual deal on the Greek debt are hard to predict at this stage. Discussions on Greece's debt sustainability and its potential rate of economic growth continue to occupy the public policy debate in both Greece and the European Union. ${ }^{19}$ Discussions on the broader issue of European economic growth and the need to boost cross-country public investment under the so-called "Junker plan" are also occupying the agendas of European Prime Minister Summits since late 2014.

In this article we analyzed the economic, institutional and political dilemmas surrounding the Greek crisis, its debt sustainability, and the implications for future economic growth within the European framework. Greek debt relief is a complex process, filled with EMU, IMF and country politics. The article offers a number of suggestions for debt relief in Greece and for promoting future growth in Europe. With economic growth emerging as an issue of critical importance for both Greece and the EU, we have examined the linkages and paths from economic distress to sustainable growth.

A disciplined but flexible long-term policy in balancing the government budget is proposed, one that would avoid fiscal pro-cyclicality within a growth-linked debt framework. For such a framework to succeed, necessary ingredients include effective structural reforms and public intangibles investments. These would help ensure an efficient operation of the economy and of market institutions and would simultaneously reduce the negative impact of fiscal austerity

19. The Eurogroup decisions of May 2016 have shaped the framework of the future solution, postponing the debt sustainability issues to after the end of the three year adjustment program 2015-2018. 
measures. Government successions should respect and secure the above conditions and try to keep them above politics, ensuring inter-generational fairness and time consistency. Policy effectiveness, enforceability and ensuring sufficient investor demand for debt relief instruments, like the November-December 2017 bond swap, remain serious considerations. Real options perspectives and insights could prove useful in addressing debt relief, ensuring balanced public budgeting and economic growth, and enriching the scope of public policy discussion both in crisis countries such as Greece and the Euro Area.

Accepted by: Prof. P. Theodossiou, PhD, Editor-in-Chief, July 2018

\section{References}

Bank of Greece. 2018. Report on Monetary Policy (in Greek) (June).

Bank of Greece. 2012. The Restructuring of the Greek Sovereign Debt. pp. 12-13, in Report on the Recapitalization and Restructuring of the Greek Banking Sector (December).

Blanchard, O.J. 2015. Greece: Past Critiques and the Path Forward. IMF direct, July 20, available at: https://blog-imfdirect.imf.org/2015/07/09/ greece-past-critiques-and-the-path-forward/

Blanchard, O.J., and Leigh, D. 2013. Growth forecast errors and fiscal multipliers. American Economic Review 103(3): 117-120.

Boomsma, T.K., and Linnerud, K. 2015. Alternative Renewable Electricity Support Schemes under Market and Policy Uncertainty. ROC.

Claeys, G.; Leandro, Á.; and Mandra, A. 2015. European Central Bank quantitative easing: the detailed manual. Bruegel Policy Contribution 2.

Chrysoloras, N. 2014. What SYRIZA Says About Greece's Economy, Its Debt and the Euro. Bloomberg (December 18), available at: http://www.bloomberg.com/news/articles/2014-12-18/what-syriza-says-a bout-greece-s-economy-its-debt-and-the-euro

Council of the European Union. 2011. Statement by the heads of State or Government of the Euro Area and EU Institutions (July 21).

Darvas, Z. 2012. The Greek debt trap: an escape plan. Policy Contribution 19.

De Villemeur, E.B.; Ruble, R.; and Versaevel, B. 2015. Innovation and Imitation in Dynamic Duopoly. ROC.

Dias, J.C.; Larguinho. M.; and Braumann, C. 2015. Entry and Exit Decisions under Output-Price Uncertainty: A Generalized Class of 1-D Diffusions. ROC.

Dotsis, G., and Milonas, N. 2015. Valuing Production Switch Options in Commodities. ROC. 
Greek Sovereign Debt: Addressing Economic Distress \& Growth in the Euro Area 31

Eurogroup. 2012. Eurogroup Statement on Greece (November), available at: http://www.consilium.europa.eu/uedocs/cms Data/docs/pressdata/en/ecof in/133445.pdf

Eurogroup. 2014. Eurogroup Statement on Greece (December), available at: http://www.consilium.europa.eu/uedocs/cms data/docs/pressdata/en/ecof in/146112.pdf

Eurogroup. 2016. Eurogroup Statement on Greece (May 2016), available at: http://www.consilium.europa.eu/en/press/press-releases/2016/05/24-euro group-statement-greece/

European Central Bank. 2016. More details on the public sector purchase Program (PSPP) - Questions \& answers (June), available at: https://www.ecb.europa.eu/mopo/implement/omt/html/pspp-qa.en.html

European Commission. 2012. The Second Economic Adjustment Program for Greece. European Economy. Occasional Papers 94 (March).

European Commission. 2015a. Information from the European Commission on the latest draft proposals in the context of negotiations with Greece. European Commission - Press Release (June 28), available at: http://europa.eu/rapid/press-release IP-15-5270 en.htm

European Commission. 2015b. Proposal on List of Prior Actions Required by the Greek Government as of June 262016 (June 28), available at: http://europa.eu/rapid/press-release IP-15-5270 en.htm

European Stability Mechanism. 2014. Extension of the EFSF Program and EFSF bonds for Greece (December 2014), available at: http://www.efsf.europa.eu/mediacentre/news/2013/extension-of-the-efsfProgram-and-efsf-bonds-for-greece.htm

European Stability Mechanism. 2015. The Third Economic Adjustment Program for Greece. available at: http://www.consilium.europa.eu/en/ policies/financial-assistance-eurozone-members/greece-Program/

European Stability Mechanism. 2017. Explainer on ESM short-term debt relief measures for Greece (December 4), available at:https://www.esm.europa.eu/ press-releases/explainer-esm-short-term-debt-relief-measures-greece

Flanagan, M., and Paxson, D. 2015. Real Euro Sovereign Debt Delinquency and Default Options (adaptation of Mortgage Renegotiation and Strategic Default: Nash Bargaining in U.S. Residential Mortgages). ROC.

Gabriele, C.; Erce, A.; Athanasopoulou, M.; and Rojas, J. 2017. Debt Stocks Meet Gross Financing Needs: A Flow Perspective into Sustainability. Working paper Series, European Stability Mechanism.

Gogos, S.; Monokroussos, P.; and Stamatiou, T. 2015. Grexit and Why It Will Not Happen: Catastrophic for Greece and Destabilizing for the Euro (June), available at: https://ssrn.com/abstract $=2616278$

Hart, O., and Moore, J. 1998. Default and renegotiation: A dynamic model of debt. The Quarterly Journal of Economics CXIII(1).

Hellenic Republic. 2014. 2015 General Government Budget, (in Greek), Ministry of Finance, November, available at: http://minfin.gr/sites/default/ files/financial files/EISHGHTIKH $\% 2$ BEKTESH\%2B2015\%2BGR.pdf 
Hellenic Republic. 2017. Public Debt Bulletin. no. 87, Public Debt Management Office (September).

Hellenic Republic. 2017. Public Debt Bulletin. No 88, Public Debt Management Office (December).

Hellenic Republic. 2018. Public Debt Bulletin. No 89, Public Debt Management Office (March).

Igrejas, R.; Cordeiro, L.; Brandão, L.; and Motta, L.F.J. 2015. Valuation of a Staged PPP Contract in Brazil: When is Abandonment Not an Option?. ROC.

Independent Evaluation Office (IEO). 2016. The IMF and the Crises in Greece, Ireland, and Portugal. The Independent Evaluation Office of the International Monetary Fund (July 8), available at: http://www.ieo-imf.org/ ieo/files/completedevaluations/EAC REPORT\%20v5.PDF

International Monetary Fund. 2010a. Board Meeting for Greece's Request for an $S B A$ ( May 9, 2010).

International Monetary Fund. 2010b. Greece: Request for Stand-By Arrangement. IMF Country Report no. 10/110 (May).

International Monetary Fund. 2012a. World Economic Outlook: Coping with High Debt and Sluggish Growth (October).

International Monetary Fund. 2012b. Greece: Request for Extended Arrangement Under the Extended Fund Facility. - Staff Report; Staff Supplement; Press Release on the Executive Board Discussion; and Statement by the Executive Director for Greece, IMF Country Report No. 12/57 (March).

International Monetary Fund. 2014. Greece: Fifth Review under the Extended Arrangement under the Extended Fund Facility, and Request for Waiver of Nonobservance of Performance Criterion and Reshaping of Access. Staff Report; Press Release; and Statement by the Executive Director for Greece, IMF Country Report no. 14/151 (June).

International Monetary Fund. 2015a. Greece: Preliminary Debt Sustainability Analysis. IMF Country Report no. 15/165 (June 26).

International Monetary Fund. 2015b. Greece: An Update of IMF Staff's Preliminary Debt Sustainability Analysis. IMF Country Report no. 15/186 (July 14).

International Monetary Fund. 2016. Greece: Preliminary Debt Sustainability Analysis - Updated Estimates and Further Considerations. IMF Country Report no. 16/130 (May 23).

International Monetary Fund. 2017. Greece, IMF Country Report no. 17/40 (February).

Juncker, C.J. 2015. Transcript of President Jean-Claude Juncker's press conference on Greece. European Commission-Speech (June 29), available at: http://europa.eu/rapid/press-release SPEECH-15-5274 en.htm

Koussis, N.; Martzoukos, S.H.; and Trigeorgis, L. 2017. Corporate liquidity and dividend policy under uncertainty. Journal of Banking and Finance 75: 200-214. 
Greek Sovereign Debt: Addressing Economic Distress \& Growth in the Euro Area 33

Landon, T. Jr. 2015. Greek Debt Vastly Overstated, Investor Tells the World. The New York Times (February 20), available at: http://www.nytimes.com/ 2015/02/21/business/dealbook/greek-debt-is-vastly-overstated-an-investo r-tells-the-world.html? $\mathrm{r}=0$

Lavrutich, M.; Kort, P.; and Huisman, K. 2015. Capacity Choice in a Duopoly with Endogenous Exit. ROC.

Meghir, K.; Pissarides, C.; Vayanos, D.; and N. Vettas (Editors). 2017. Beyond Austerity: Reforming the Greek Economy. MIT Press.

Meier, M., and Mecikovsky, A. 2015. Do Plants Freeze Employment upon Uncertainty Shocks?. ROC.

National Association of State Budget Officers (NASBO). 2015. Budget processes in the States.

Rogoff, K., and Reinhart, C. 2010. Growth in a Time of Debt. American Economic Review 100(2): 573-8.

Schumacher, J., and di Mauro, B.W. 2015. Diagnosing Greek Debt Sustainability: Why is it so hard? Brookings Institution (September 10).

Serafeim, G. 2015. Greece's Debt: Sustainable? Harvard Business School, N2-115-063 (June 16)

Strupczewski, J. 2014. Exclusive: Euro zone considers three bailout exit options for Greece. Reuters, Brussels (November 6), available at: http://www.reuters.com/article/us-greece-bailout-eurozone-exclusive-idU SKBN0IQ1KV20141106

SYRIZA. 2014. The Thessaloniki Program (September), available at: https://www.syriza.gr/article/SYRIZA---THE-THESSALONIKI-PROGR AM.html\#.V5xToGWaGOo, and at: http://socialistnetwork.org/the-newProgram-of-syriza/ (from The Socialist Network).

Tsekrekos, A., and Yannacopoulos, A. 2016. Optimal switching decisions under stochastic volatility with fast mean reversion. European Journal of Operational Research 251(1): 148-157.

Tsujimura, M. 2015. Pollutant Abatement Investment Policy under Ambiguity. ROC.

Wikipedia, The Free Encyclopedia, 2017, Deficit spending. (2017, October 6). Retrieved 05:26 (November 14).

Wikisource, Treaty on Stability, Coordination and Governance in the Economic and Monetary Union. (2013, April 3). Retrieved 05:20 (November 14), available at: https://en.wikisource.org/w/index.php?title= Treaty on Stability, Coordination and Governance in the Economic and Monetary Union\&oldid=4372814 from https://en.wikipedia.org/w/ index.php?title $=$ Deficit spending\&oldid $=804102497$

Zettelmeyer, J.; Trebesch, C.; and Gulati, M. 2013. The Greek debt restructuring: an autopsy. Economic Policy 28(75): 513-563.

Note: ROC is Real Options Conference. 